Article

\title{
Hydropower Royalties: A Comparative Analysis of Major Producing Countries (China, Brazil, Canada and the United States)
}

\author{
Pierre-Olivier Pineau ${ }^{1, *}$, Lucile Tranchecoste ${ }^{2}$ and Yenny Vega-Cárdenas ${ }^{3}$ \\ 1 HEC Montréal, Montreal, QC H3T 2A7, Canada \\ 2 Faculty of Law, Université Laval, Ville de Québec, QC G1V 0A6, Canada; lucile.tranchecoste@gmail.com \\ 3 Faculty of Law, Université de Montréal, Montreal, QC H3T 1J7, Canada; yenny.vega.cardenas@umontreal.ca \\ * Correspondence: pierre-olivier.pineau@hec.ca; Tel.: +1-514-340-6922
}

Academic Editor: Julio Berbel

Received: 18 January 2017; Accepted: 14 April 2017; Published: 20 April 2017

\begin{abstract}
Hydropower is the leading renewable source of electricity generation and a low emission energy source. In order to be developed sustainably, it is important that its costs and benefits are adequately set and distributed. Different mechanisms, such as royalties, can be used for this purpose. Governments have usually kept hydropower royalty rates low, without internalizing negative externalities. This strategy is inefficient because it leads to larger electricity production and consumption, and hence exacerbates environmental impacts. This paper reviews the criteria proposed and used to set hydropower royalties. It also compares practices of the four main hydropower producers in the world: China, Brazil, Canada and the United States. Results show that royalty rates and distribution policies are determined in an arbitrary and unsystematic manner, but also that water use is usually undervalued. In order to encourage the development of this key renewable resource, in a sustainable and responsible way, national and international efforts should be made to rationalize and harmonize hydropower royalty rates.
\end{abstract}

Keywords: hydropower; royalty; China; Brazil; Canada; United States

\section{Introduction}

Hydropower is the leading renewable source of electricity generation, with $16.3 \%$ of the world output compared to only $5.7 \%$ for other renewables [1]. In addition to being a low emission energy source, it has many benefits, often including storage, low ramp-up time and water management opportunities [2]. To be used and developed sustainably, it is important that its costs and benefits are adequately set and distributed [3]. Different mechanisms, such as royalties, can be used for this purpose. Imposing such types of financial instrument on developers of these natural resources is not, however, as common as it is in the oil, gas or coal sectors.

Furthermore, governments have usually kept hydropower royalty rates low, without internalizing negative externalities. This strategy is inefficient, by exacerbating environmental impacts through larger electricity consumption and production [4]. Governments have indeed generally preferred to keep hydroelectricity prices low, through low royalty rates, for the benefit of consumers [5].

Very little has been written about the criteria that should be considered to set hydropower royalties and even less on international comparison of hydropower royalties. This paper addresses these two issues. First, we identify different methods that have been used to establish a financial compensation, and, second, we compare hydropower royalties in the world of four main hydropower producers: Brazil, China, Canada and the United States. Together, they account for more than half of the global hydropower production [1]. 
Only two documents proposing an international comparison of hydropower royalties were identified: Brubaker [6] and UNIPEDE [7], with very limited depth. A more recent report describes the US annual charge system [8]. Other articles found mainly focus on water laws for water withdrawals and water use, but with no emphasis on charges for hydropower [9-12]. In an Italian context, Ref. [13] estimates the value of the hydroelectric rent that could be used to estimate the level of hydropower royalty rates. More recently, Glachant, et al. [14] looked at the different European regimes for granting rights to use hydropower, and have observed major discrepancies, concluding that competition in this sector could be an issue, but that distortions from unharmonised regimes are even more problematic. Their focus is, however, European, when none of the world's largest hydro producers are in Europe.

After reviewing the practices adopted by governments or suggested in the literature for hydropower royalties, we present in Section 3 the royalty rates approach adopted by the four largest hydropower producers in the world. Section 4 discusses how these practices could be improved.

\section{Materials and Methods}

We have conducted a systematic review of legislation, regulations and policies within the four largest producers of hydroelectricity, in order to better understand their system and hydropower royalties.

Our information originates essentially from a literature search, accessible data from ministry websites as well as from completing interviews with key informants from these ministries. This document is designed to deal with basic concepts through a general description of the legal provisions and hydropower royalty structure, in order to point at some policy improvements.

The concept of royalties evokes compensation to the right of use and the right to obtain some economic benefits from natural resources. In the case of hydropower royalties, they are established as compensation for the right of use water resources to produce electricity. In fact, as water and energy are interconnected, it is very important to manage them together [15].

The tax structure for hydropower varies from country to country as does the amount of taxes paid. Nevertheless, we have identified some general approaches that are commonly used in several countries and other methods that are highly recommended by the literature on this topic.

First of all, the social and environmental approaches suggest that in order to reduce or mitigate negative externalities associated with water overuse caused by dams, governments should levy a tax to compensate the damages caused to the environment and to the local communities. These possible negative externalities are, for instance, water pollution, environmental damages, degradation or loss of riparian habitat, evaporation [16] and negative impact to aquatic species. Nevertheless, some authors bring to light the fact that we have to suppose that society has accepted some level of environmental degradation to cover some energy needs [17]. In this sense, countries such as Brazil have found royalties necessary to compensate people who are harmed as a result of the construction of dams $[18,19]$.

In the same direction, some authors propose charging royalties depending on the dam's size, as it is recognized that large dams imply massive negative environmental and social impacts that raise questions about the sustainability of those projects [20,21]. Some provinces of China have adopted this approach, but not the one of Hubei, where the Three Gorges dam, the world's largest hydroelectric power station, is installed. In fact, this enormous dam is controversial because of ecological degradation and displaced communities [15].

Other approaches propose compensating for the cost of modifying water ways. This method considers the length of the watercourse made dry as a result of the diversion or based on the tonnage of extracted alluvial materials [18]. As we will further expose, California, in the United States, has adopted a royalty system that includes this consideration. 
The most common practice found in China, several US states and provinces in Canada is to charge a royalty based on electricity generation. Such charges can be stated as fixed tax per unit of electricity generated [7]. Others prefer to charge a royalty based on the revenues from hydroelectric sites as Brazil and Ontario do. Nevertheless, some authors advise that an optimal system of taxation should be based on profits rather than based on production, provided permissible expenses are clearly defined [22].

Other practices are based on water use for hydropower production. In fact, even if hydropower production is not a consumptive use of water, it requires the construction of reservoirs, which modify the aquatic environment. Hence, royalties can be stated as fixed charges per unit of water used [15]. The purpose of this approach is to recognize the value of water. It tends to value not only the importance of good water quality, but also the availability of this resource for different uses. This method can also be seen as an ad valorem royalty because it is not linked to the project profitability, but extracts some rent from the inherent value of the resource [5]. As we will see, California has adopted this approach and has created a water fund where those royalties go.

We have found other proposals for royalties based on the free cash flows of a company or the capital base of the firm. However, this method raises some questions related to the difficulty of reconstructing the free cash flows of a company [23].

Finally, other approaches present the advantages of establishing a scarcity rent that would consider the unit cost of electricity generation if hydro sites were unavailable or very limited [23]. This method considers the fact that there are a limited number of sites that are suitable for power generation and that they have seasonal limitations. It is also being proposed to charge a differential rent that could result from the ability of some hydroelectric sites to generate electricity at lower cost than other alternative generation technologies [5]. In fact, the differential rent depends on the way the resource is being used and on the different characteristics of the existing watercourse. Hydro rent can actually include both scarcity and differential rents [5].

Furthermore, it is important to know that some countries have chosen to provide consumers with rebates on the price of electricity as part of the financial compensation they should provide to the community. This position is criticized because this policy encourages the over use of electricity [23]. Economists highlight the fact that when hydro developments are international in scope, it is better to establish explicit royalty mechanisms that will help with apportioning the rent between the co-owners of water resources, rather than embodying the hydro rent into the electricity price, which leads to an inequitable share of the rent favoring consumers [5].

In the next section, we analyze the practices of the world's largest hydroelectric producers.

\section{Results}

We provide an overview of the political and legal framework governing hydroelectricity generation in each of the main four producers of hydropower in the world: China (920 TWh), Brazil (391 TWh), Canada (392 TWh) and the United States (290 TWh), together accounting for more than $50 \%$ of the world's hydro production in 2013 [1]. We focus our analysis on the royalty rate structure. Although three of these countries have in common a federal political structure, while China has a central government with limited power to provinces, their approaches to hydropower management differ by providing more or less power to their states or provinces, as Table 1 illustrates. In each of the next four subsections, we cover in more details these countries. 
Table 1. Main component of the hydropower royalty governance in China, Brazil, Canada and the United States.

\begin{tabular}{cccl}
\hline Country & $\begin{array}{c}\text { Level of Government } \\
\text { in Charge }\end{array}$ & Governing Laws & \multicolumn{1}{c}{ Administration } \\
\hline China & $\begin{array}{c}\text { Provincial with central } \\
\text { government } \\
\text { coordination }\end{array}$ & $\begin{array}{c}\text { Water law of the PRC (2002) } \\
\text { and provincial laws }\end{array}$ & $\begin{array}{l}\text { Department of Water Resources of } \\
\text { the State Affairs Council + Local } \\
\text { departments of Price control, } \\
\text { Water resources and Treasury }\end{array}$ \\
\hline Brazil & $\begin{array}{c}\text { Federal (National System } \\
\text { of Water Resource } \\
\text { Management) }\end{array}$ & $\begin{array}{c}\text { "Codigo De Aguas", } \\
\text { "Lei No. 9074, 1995" and }\end{array}$ & $\begin{array}{l}\text { ANEEL (Ministry of Mines and } \\
\text { Energy) + ANA (Ministry of the } \\
\text { Environment) }\end{array}$ \\
\hline Canada & Provinces & Different for each province & Usually the Ministry of Energy \\
\hline US & $\begin{array}{c}\text { Federal with States } \\
\text { residual jurisdiction }\end{array}$ & Federal Power Act & $\begin{array}{l}\text { Federal Energy Regulatory } \\
\text { Commission (FERC) with } \\
\text { States' Water Department }\end{array}$ \\
\hline
\end{tabular}

\subsection{China}

China is the largest producer of hydroelectricity in the world since 2004 [24]. China has the richest water potential in the world, but water resources are asymmetrically distributed over its territory: $70 \%$ of the hydropower capacity is in four southwest provinces (Sichuan, Yunnan, Guizhou and Chongqing), while demand is located in coastal cities. The project "transmission of electricity from the West of China" has been developed to mitigate this problem [25] and is undoubtedly going to increase hydroelectric production in the years to come. In 2013, there were 46,758 hydropower plants in China, with a combined capacity of 332,889 MW [26].

\subsubsection{Legal Framework}

Even though local governments in China started collecting water royalties from 1980, it was in 1988 that the Central government adopted the Water Law of the People's Republic of China, which formally established a capacity for water management in provinces, autonomous regions and municipalities. It states that the power to levy hydraulic charges and make the royalty system is rooted at the local level. However, with the revision of the law in 2002, the central authority has intervened periodically to regulate at the national level and to coordinate between regions and the federal government [27]. A formal system of permits and charges has been put in place, enacted and monitored at the federal level under the responsibility of the Ministry of Water Resources of the Council of State. This formal system still leaves the authority to manage water resources within the local departments of water resources. The originality of the Chinese system lays in the fact that while the royalty system was first established autonomously by provincial governments, and still operates at a provincial level, the federal government intervenes with a policy framework growing stronger, in an attempt to unify the various systems.

In China, the central government manages the system of licenses and has enacted detailed regulations for levying hydraulic royalties. Thus, the management of water resources functions according to three principles: the responsibility of three hierarchical levels of government (provincial, municipal and district), the co-management by the regional governments and the administrative institutions of the river basin, and, finally, a co-fixation of the fee by a group of regional departments, then approved at the central level.

As a result, as we will also see for Canada, there are a variety of rates for hydraulic charges administered by the different provinces (see Table 2). Since 2011, China is on the path to unify the management of water [28]. Moreover, in light of Article 12 of the 2002 Water Law, the Ministry of Water Resources under the State Council and its provincial counterparts are responsible for unifying water resources management. According to Article 3 of Regulation on the Administration of the License for Water Drawing and the Levy of Water Resource Fee [29], the various water administrative departments 
are responsible for organizing, implementing, supervising, and administering the institution of license for water drawing. However, some trans-provincial water transfer projects' royalties are not necessarily subject to the Ministry of Water Resources because they are decided by the relevant provincial governments.

Table 2. Hydropower royalty rates in China (using US $\$ 1=6.66$ Chinese Yuan).

\begin{tabular}{|c|c|c|}
\hline Province & Annual Charge Basis & Royalty Rates \\
\hline Hubei & & $\$ 0.75 / \mathrm{MWh}$ \\
\hline Sichuan & & $\$ 0.75-1.20 / \mathrm{MWh}$ \\
\hline Yunnan & & $\$ 0.75-2.25 / \mathrm{MWh}$ \\
\hline Guangdong & & $\begin{array}{r}<50 \mathrm{MW} \\
\$ 0.75 / \mathrm{MWh} \\
\geq 50 \mathrm{MW} \\
\$ 1.05 / \mathrm{MWh}\end{array}$ \\
\hline Fujian & & $\$ 1.20 / \mathrm{MWh}$ \\
\hline Hunan & & $\$ 0.45 / \mathrm{MWh}$ \\
\hline Zhejiang & & $\$ 1.20 / \mathrm{MWh}$ \\
\hline Guizhou & & $\$ 0.60-2.25 / \mathrm{MWh}$ \\
\hline Qinghai & & $\$ 0.75 / \mathrm{MWh}$ \\
\hline Gansu & Power output in all cases & $\begin{array}{r}<5000 \mathrm{MW} \\
\$ 0.45 / \mathrm{MWh} \\
\geq 5000 \mathrm{MW} \\
\$ 0.75 / \mathrm{MWh}\end{array}$ \\
\hline Jiangxi & & $\$ 0.45 / \mathrm{MWh}$ \\
\hline Henan & & $\begin{array}{r}<5 \mathrm{MW} \\
\$ 0.75 / \mathrm{MWh} \\
\geq 5 \mathrm{MW} \\
\$ 1.50 / \mathrm{MWh}\end{array}$ \\
\hline Chongqing & & $\$ 0.75 / \mathrm{MWh}$ \\
\hline Shanxi & & $\$ 0.75-1.20 / \mathrm{MWh}$ \\
\hline Tibet & & $\$ 0.30 / \mathrm{MWh}$ \\
\hline Xinjiang & & $\$ 0.45 / \mathrm{MWh}$ \\
\hline Heilongjiang & & $\$ 1.50 / \mathrm{MWh}$ \\
\hline
\end{tabular}

Hydropower royalties in China have been enacted before permits have been required: indeed, while hydraulic charges appeared with the 1988 Water Law, the legislative status of the water use permits and of the water charges for hydropower was only established in 2002 with the revision of this law. Nonetheless, although the permit system was enacted at the federal level, permits are issued locally relatively freely. The Chinese system parallels the North American model by its lack of uniformity.

\subsubsection{Hydropower Royalty Structure}

In China, the hydropower royalty is clearly considered as a compensation that the operator of a plant shall pay to use the public commodity (hydropower) conceded to him. The government, which has been trying to regulate the matter since 2006, set minimum and maximum rates for royalties, leaving the provinces free to implement their own rates within these limits.

The royalty rate is calculated according to the actual power output of the plant and the local water fees [30] and the rate is established jointly by the ministries of price control, water resources 
and by the Treasury of the provinces, autonomous regions and municipalities, and must be approved by the government at the same level. It is subsequently registered at the ministries of price control, water resources and at the treasury [30]. In 2009, the hydropower royalty was jointly published by the National Development and Reform Commission, the Treasury, and the Ministry of Water Resources, proposing limits to the hydropower royalty rates that should be henceforth between 5 and 8 Chinese Yuan Renminbi (CNY)/MWh (between US $\$ 0.75$ and US $\$ 1.25 / \mathrm{MWh}$ ).

Hydropower royalties in each province greatly vary, even beyond these limits: the most economically developed provinces in southeast China, specifically the provinces of Fujian, Guangdong and Zhejiang, impose a high fee (about US $\$ 1.25 / \mathrm{MWh}$ ), while less developed regions, for example, the autonomous region of Tibet, require lower fees (for instance, US\$0.3/MWh) (see Table 2 [27]).

Some provinces have differentiated rates for large and small hydro, but not the province of Hubei, where the Three Gorges dam is installed. The royalty rate adopted by this province has followed the minimum rates suggested by the central government, US\$0.75/MWh.

\subsubsection{Royalty Distribution Policy}

Concerning the royalty distribution policy, in the pursuance of Article 35 and Article 36 of State Council of China [29], the levied water resource fees shall be separately turned over to the treasuries of the Central Government and of the local governments. The collection shall be mainly used for conservation, protection and administration of water resources, or may be used for reasonable exploitation of water resources, as specified in State Council of China [30]. The allocation and use of fees collected from the Three Gorges dam is jointly decided by the Ministry of Finance and Ministry of Water Resources. Their decisions have to be approved by the State Council.

In conclusion, even if the central government has given a national framework to set the hydropower royalties in China, they vary in price and in approach from one province to another. Nevertheless, the main criteria in all provinces is the power output of the station, and, in some provinces, the size of the power plant is taken into consideration.

\subsection{Brazil}

Few countries in the world enjoy a water system as generous as the Brazilian one. It is estimated that out of the 113 trillion cubic meters of water available for terrestrial life, 17 are in Brazil, which means that $15 \%$ of the existing fresh water in the world [31].

\subsubsection{Legal Framework}

The legal requirements associated with the development of hydroelectric projects and the royalty system are clearly enacted at the federal level. The use of hydropower potential is subject to the authorizations and concessions regime established by the Water Code (Codigo de Aguas) and regulated by Law 9074 of 7 July 1995 (Lei 9074) in virtue of which the federal government establishes the permissions but also the hydropower royalty rates. Nevertheless, the Brazilian Constitution shares the competence on national water-courses between the federal government and states.

The Brazilian Constitution enacted in 1988 mentions that states, the Federal District, municipalities, as well as the Federal government, should share the profits of oil or natural gas exploration, as well as water resources for the purpose of power generation and other mineral resources by getting financial compensation and royalties for such exploitation.

\subsubsection{Hydropower Royalty Structure}

In 1989, a specific law about financial compensation (Lei 7.990/1989) was established to regulate the use of water resources for the purpose of electricity generation. The amount currently stated that must be paid by concession holders and permits for any hydraulic potential is $6.75 \%$ of the value of the energy produced, based on the energy generated. Initially, plants with nominal capacity of less than 
$10 \mathrm{MW}$ were exempted from this payment. This exemption was extended to plants with a capacity not greater than $30 \mathrm{MW}$ [32].

In general, the Financial Compensation (FC) to be paid is calculated through a standard formula: $\mathrm{FC}=6.75 \% \times$ power generated in the month $\times$ reference rate. The reference rate ("Taxa annual de referencia") is set annually through an Agência Nacional de Energia Elétrica (ANEEL, the Brazilian Electricity Regulatory Agency) Resolutions, and the rate (see Table 3) is revised by the federal government every four years [33].

Table 3. Hydropower royalty rates in Brazil (using US $\$ 1=3.23$ Brazilian Real).

\begin{tabular}{ccc}
\hline State & Annual Charge Basis & Royalty Rates \\
\hline All Brazilian states & Revenue of power output & $6.75 \% \times$ sales value $/ \mathrm{MWh} \approx \$ 1.58 / \mathrm{MWh}$ \\
\hline
\end{tabular}

\subsubsection{Royalty Distribution Policy}

The above-mentioned $6.75 \%$ is divided in two parts: $6 \%$ and $0.75 \%$. The $6 \%$ is allocated to municipalities affected by the dams and the states where dams are located (Lei 7.990/1989). More specifically, this $6 \%$ is divided between states and municipalities, each getting $45 \%$ of the total amount. The remaining 10\% goes for the federal government: the Ministry of the Environment gets 3\%, the Ministry of Mines and Energy also 3\% and the National Fund for Scientific and Technology obtains $4 \%$, which is managed by the Ministry of Science and Technology. The share concerning the Ministry of Environment is dedicated to the implementation of the National Water Resources Policy and the National Water Resources Management System, as well as the management of the national hydro-meteorological network (Lei 7.990/1989).

The remaining $0.75 \%$ is also allocated to the Ministry of the Environment, in order to further support the implementation of the National Water Resources Policy and the National Water Resources Management System (Lei 9984/2000).

\subsection{Canada}

Canada, like Brazil, produces about $10 \%$ of the world's hydropower [1]. This is made possible because Canada holds 7\% of the world's renewable fresh water resources [34].

\subsubsection{Legal Framework}

Likewise Brazil, the Canadian federal legal system operates on a shared jurisdiction between the federal government and the provinces. The division of powers has been set in detail by the Constitutional Law of 1867. In fact, in light of articles 109 and 117 of the Constitutional Law, provinces are owners of the natural resources that are in their territories. In addition, Articles 92 and 92A of the Canadian Constitution state that provinces enjoy exclusive legislative power for the management of their natural resources that are found in their territories. Thus, water and hydropower management are under provincial responsibilities. The federal government is responsible for managing water and natural resources that are found in federal lands (e.g., national parks), First Nation reserves, as well as Nunavut and Northwest Territories. The federal government can also adopt legislation related to interprovincial waterways, but, in practice, those waterways are managed on a mutual cooperation basis between riparian provinces [35].

Since Canadian provinces enjoy exclusive legislative power for the management of water resources and the hydropower sector located on their territory, they have the ability to impose rights on water use and electricity production itself using licenses and royalties [36]. Consequently, each one has developed its own management system, and hence, this sector, as the royalties system, varies from one province to another. 


\subsubsection{Hydropower Royalty Structure}

In Canada, all provincial governments charge a hydropower royalty to plant operators, except New Brunswick and Alberta, where hydropower production remains relatively small.

The federal government and the province of Newfoundland and Labrador have fixed a unique annual royalty: the federal one is based on water used or stored (Dominion Water Power Regulations), while the Newfoundland and Labrador ones are related to the lease of water power. Precisely, the annual rent for a water use license shall be Can $\$ 0.80 / \mathrm{MWh}$ of power generated (Water Power Rental Regulations, 2003 under the Water Resources Act).

In Quebec, the main producer of hydroelectricity in Canada with 183 TWh or $49 \%$ of the Canadian total in 2013 [37], production is largely dominated by the government-owned enterprise Hydro-Quebec. The legal framework of this province specifies that holders of hydraulic power rights are subject to an inflation-adjusted charge of Can\$3.852/MWh, in 2015 (Watercourses Act, R-13). Additional contractual charge and various one-time fee may also be charged.

Hydro-Quebec and private hydropower producers have also to pay a rent for the lease of the water property occupied by their hydropower installations. This rent is fixed at the higher amount between the $10 \%$ of the value of the water property, up to five hectares (ha) used, or Can\$318 (per 5 ha) (regulation respecting the water property in the domain of the State, Art. 23). This amount is not significant. Hydro-Québec, contrary to private hydro-power producers, is exempted from municipal taxes, which is deplored by municipalities [38].

The government of Ontario introduced in 2000 legislation intended to encourage the development and expansion of environmentally friendly hydro-electric generating stations. In 2001, the property taxes and water rental charges paid by hydro-electric generating station owners and water power leaseholders were replaced. Nowadays, these producers have to pay taxes and charges on the gross revenues of hydro-electric generating stations, called the "Gross Revenue Charge" (GRC). It is composed of a property tax component, payable by the owner of the hydro-electric generating station (private or public), and a tax related to the right of producing hydropower (Electricity Act, 1998).

Every hydropower plant owner benefits from the lower rates on the gross revenue from the first $700 \mathrm{GWh}$ of annual generation for each station; see Table 4. Some exceptions are provided to the applicability of these royalties (i.e., hydropower generated at Niagara Parks).

Royalty rates in Ontario have been subject to criticisms. In fact, rates are considered below the market value as some authors have highlighted: "actual water royalty rates were approximately $\$ 1.9$ billion below their market value" [4]. It is assumed that the Ontario government keeps, in this way, artificially low electricity prices. Indeed, this approach encourages the overconsumption and overproduction of hydro sites.

British Columbia has also maintained low hydropower rates. In fact, even if this province has reviewed the water pricing, under the 2014 Water Sustainability Act that came into effect in January 2016, the rates related to hydro-electric power generations have not been part of this water pricing review.

In this province, there are different types of hydropower royalties. First, a royalty based on the storage capacity of the station that is intended to "reimburse the expenses incurred to preserve the right to use water" [39]. The rates for storage supporting waterpower production for 2016 are the equivalent to approximately Can $\$ 0.002$ per 1000 cubic meters; see Table 4 . Then, a royalty based on electricity generation and capacity is charged. Finally, if the dam is on crown lands, there is a royalty payment due for the permit over crown land occupied by a dam, a minimum of Can $\$ 100$ per year or Can\$120/ha per year in 2016 [40].

There is no hydropower power royalty in New Brunswick as such. A charge has to be paid for the rental of crown land for the production of power, but this also applies to wind energy [41]. New Brunswick Power, the main hydropower producer of the province, owns land of its plants. No information was found on the other two hydropower producers (JD Irving and Algonquin Power). 
In Alberta, the 2000 Water Act contains no provision regarding the imposition of charges related to the production of hydroelectricity. Although the law states that a charge may be required by the Ministry of Environment for hydropower production (Article 168.3), "there is no associated price to the water" used in Alberta [42].

In Manitoba, the main producer of hydroelectricity is the state-owned company Manitoba Hydro. As for all producers of hydropower in the province, it must pay two royalties. One related to the right of use crown lands: Can\$1.80 per acre per year (Water Power Act, article 48-3.1). The other royalty is related to water use, which is based on the greater of the horsepower (hp) capacity or the horsepower output of the station; see Table 4 (with rates converted in $\$ / \mathrm{kW}$ and $\$ / \mathrm{MWh}$ ).

Saskatchewan follows a similar model, defined in The Water Power Rental Regulations, established in 2006. All hydropower producers pay the greater of the capacity fee of Can\$1000/MW per year, or an energy fee of Can\$5.10/MWh (2015 values). This energy fee changes every year [43].

In Nova Scotia, the fee regulation made under the Environmental Act (N.S. Reg. 29/2012) establishes an annual administration fee of $\$ 608.84$ for the use of water for hydroelectric purposes and an annual capacity fee of Can\$2600/MW.

As it has been shown, rates and fees are mostly based on the hydropower generation in Canada. This is the case in Newfoundland and Labarador, Ontario, Quebec, British Columbia, Manitoba and Saskatchewan. In addition, some provinces as Manitoba and Saskatchewan consider the power capacity of the station, instead of only the output, whichever being greater. Ontario has opted for a different basis for the calculation of the royalty rate. The calculation is not done exclusively on the basis of the energy produced, but as its name suggests, on the gross income.

Royalty rates change in accordance with the provisions laid down by provinces. Only three provinces in Canada have opted to update periodically the royalty rate: Quebec, British Columbia and Saskatchewan. Rates are indexed annually according to the percentage increase in the consumer price index. In contrast, other provinces do not allow the evolution of the charge over time and, for example, federal annual fees are generally fixed for a period of 20 years and subsequently reassessed if the concessions themselves have a longer duration. However, this federal system only concerns a marginal share of hydropower generation.

Table 4. Hydropower royalty rates in Canada's largest hydropower provinces (production $\geq 10 \mathrm{TWh}$ ) (using US\$1 = Canadian \$1).

\begin{tabular}{|c|c|c|}
\hline Province & Annual Charge Basis & Royalty Rates \\
\hline Newfoundland and Labrador & Power output & $\$ 0.80 / \mathrm{MWh}$ \\
\hline Quebec & Power output & (indexed annually) \$3.852/MWh \\
\hline \multirow{8}{*}{ Ontario } & \multirow{8}{*}{$\begin{array}{l}\text { Gross revenue of power output } \\
\text { (using a price of } \$ 40 / \mathrm{MWh} \text { ) }\end{array}$} & Property tax rates \\
\hline & & $\leq 50 \mathrm{GWh} \quad 2.5 \%$ \\
\hline & & between 50 and $400 \mathrm{GWh}$ \\
\hline & & $4.5 \%$ \\
\hline & & between 400 and $700 \mathrm{GWh}$ \\
\hline & & $\begin{array}{r}6.0 \% \\
265 \%\end{array}$ \\
\hline & & $>700 \mathrm{GWh} \quad 26.5 \%$ \\
\hline & & $\$ 3.8 / \mathrm{MWh}$ \\
\hline \multirow{5}{*}{ British Columbia } & Capacity & $\approx \$ 2.5-4.7 / \mathrm{kW}$ \\
\hline & Power output & $\approx \$ 1.3-7.3 / \mathrm{MWh}$ \\
\hline & Storage capacity & $\$ 0.002 / 1000 \mathrm{~m}^{3}$ \\
\hline & Occupied land (dam) & $\$ 120 /$ hectare \\
\hline & Occupied land (flooded) & $\$ 7.50 /$ hectare \\
\hline \multirow{4}{*}{ Manitoba } & Greater of power output or & $\leq 200 \mathrm{MW} \$ 1.51 / \mathrm{MWh}$ or \\
\hline & capacity & $\$ 5.3 / \mathrm{kW}$ \\
\hline & & >200 MW \$3.11/MWh or \\
\hline & & $\$ 10.9 / \mathrm{kW}$ \\
\hline
\end{tabular}




\subsubsection{Royalty Distribution Policy}

Hydropower fees collected at the federal government and in Newfoundland and Labrador are intended to ensure conservation and proper use of water resources, as well as to finance programs and other measures related to the environment (Water Power Rental Regulations, 2003 under the Water Resources Act).

In the province of Quebec, these payments go to a provincial "Generations Fund", dedicated to reduce the public debt (Article 68 of the Watercourses Act). In this province, the Environment Quality Protection Act (31 (e.1)) gives to the government the possibility of creating economic instruments, such as royalties related to the use of water, to protect the environment. At the moment, there's no charge adopted by regulation to protect the environment or to cover negative externalities generated by dams. Nevertheless, Hydro-Quebec has some voluntary programs dedicated to offset the residual impacts of its transmission projects, in which the company invests $1 \%$ of the value of transmission infrastructures. Indeed, Hydro-Quebec spent Can $\$ 4.2$ million in 2014 to compensate communities for the negative impacts caused by new transmission infra-structures. Hydro-Québec also disbursed about half a million dollar yearly in an environment fund [44].

In Ontario, the Electricity Act incentivizes through lower royalty rates the construction of new stations and the enlargement of existing stations [45]. This may in fact be contradictory with the suggestion that royalties should reflect negative environmental and social impacts of large dams [15].

Almost no province in Canada has adopted a royalty system to compensate for the negatives externalities associated to dams. Indeed, only Newfoundland and Labrador uses a share of the royalties collected for water conservation and for environmental programs, and Hydro-Quebec has adopted, on a voluntary basis, a program dedicated to protect the environment.

\subsection{United States}

US hydropower accounted for 7.5\% of world hydropower generation, while about 290 TWh [1]. Three states (Washington, Oregon and Idaho) generate the majority of their power from hydropower resources, while four states (Washington, Oregon, New York and California) generate more than 20 TWh per year of hydropower [46]. As shown in Table 5, although public owners of hydropower (municipal, non-federal and federal organizations) only operate $31 \%$ of the plants, they control $73 \%$ of the US capacity, of almost 54,000 MW. Kao et al. [47] estimate that 65,500 MW of new hydro capacity could technically be developed.

Table 5. Number of plants and capacity of hydropower owners in the US, by class, 1998 [48].

\begin{tabular}{ccc}
\hline Owner Class & Number of Plants & Total Capacity (MW) \\
\hline Municipal and other & $577(24 \%)$ & $16,573(22 \%)$ \\
non-federal public & $171(7 \%)$ & $37,215(51 \%)$ \\
Federal & $37(2 \%)$ & $331(<1 \%)$ \\
Cooperative & $735(31 \%)$ & $18,209(24 \%)$ \\
Private utility & $642(27 \%)$ & $1810(2 \%)$ \\
Private non-utility & $226(9 \%)$ & $733(1 \%)$ \\
Industrial & 2388 & 74,872 \\
Total & &
\end{tabular}

\subsubsection{Legal Framework}

Unlike Canada, the US centralizes, at the federal level, part of the hydropower regulation. The Federal Power Act of 1935 gives to the Federal Energy Regulation Commission (FERC), an independent organization of the Department of Energy, the responsibility to regulate non-federal hydropower projects (this includes all hydropower projects not owned by the federal government; see Table 5). The FERC issues licenses allowing the construction and operation of dams and powerhouses and sets up different charges collected from licensees operating hydro plants. The FERC levies annual 
fees from licensees in order to "repay the U.S. government for the costs of administering the regulatory program of hydropower" and also requires charges for government land use, government's dam use or because of the upstream benefits due to projects built by the government. Nevertheless, as it is the case for Canada, US states have the primary responsibility for managing the use of water resources. Accordingly, they retain a residual authority enabling them to establish additional, discretionary, specific water rights and rent regimes through their own constitutions. Thus, the US system is characterized by a common federal framework and various state regulations.

\subsubsection{Hydropower Royalty Structure}

As already mentioned, the FERC imposes a fee, applied to all non-federal hydroelectric projects, which could be described as a "reimbursement royalty": it collects charges in order to offset administration costs. This federal charge can be supplemented with a state royalty.

Thus, New York and Oregon states additionally require a "reimbursement charge": every license shall pay an annual charge for the cost of administration of the waterpower program $[49,50]$. FERC and New York also provide a rental fee linked to the ownership of water or land by the state, for example: when the owners of a dam occupy federally owned land, the FERC also determines charges for a licensee's use of federal lands, federal dams, and Native American reservations. In New York, each licensee shall pay an annual charge for using water power sites or lands pertaining to the state [50]. However, only California, Oregon and Washington arranged for a fee directly related to the generation of hydroelectricity: each entity holding a permit for an activity involving the diversion or the use of water for hydropower generation shall pay an annual fee (California Water Code, Fee schedules, s.1525-1530, C-8, Article 1.) and Oregon Revised Statutes [49]. Finally, states like Alabama, which do not require any authorization for the production of hydroelectricity, do not collect any royalty.

The "reimbursement" fee of the FERC is calculated on the basis of the authorized installed capacity in $\mathrm{kW}$, and the annual generated power in MWh. The FERC also charges for the use of government land based on its commercial value. These fees are established by county, or by state, on a feet/acre/year basis. The schedule of these fees is updated every year, in accordance with the most recent schedule of fees for the use of linear rights-of-way prepared by the U.S. Forest Service [51].

There is also a charge for the use of government dams (Code of Federal Regulation, CFR, Title 18, Chapter 1, Subchapter B, Part $11 \S 11.3$ ) or other structures owned by the government, at the rate of: US $\$ 1 /$ MWh for the first $40 \mathrm{GWh}$ of a project, US $\$ 1.5 / \mathrm{MWh}$ for over $40 \mathrm{GWh}$, up to $80 \mathrm{GWh}$, and US $\$ 2 /$ MWh beyond $80 \mathrm{GWh}$. This annual charge is based on the gross energy production less the energy provided free of charge to the government. The FERC determines on a case-by-case basis the annual charges for pumped storage projects using a government dam or other structure.

The FERC also determines, on a case-by-case basis, the annual charges for any project using tribal lands (CFR, Title 18, Chapter 1, Subchapter B, Part 11 § 11.4) within Indian reservations and also a charge for headwater benefits (CFR, Title 18, Chapter 1, Subchapter B, Part $11 \S 11.10$ ).

The FERC administrative charges are adjusted annually (Federal Power Act (1935), 16 USC § 803, s.10).

Large hydropower states such as Oregon [49], Washington (Revised Code of Washington) and California (Water Code) charge some fees for hydro-electric production. In fact, they have decided to calculate the charges on the basis of the installed capacity, reported on the licenses for use, employing scales, but each state has its own way of determining the rate (see Table 6).

It must to be considered that fees do not apply to any hydropower project owned by the US government if the use of water for the generation is $50 \mathrm{hp}(37 \mathrm{~kW})$ or less.

In California, the Water Code establishes some emergency regulations and fees for hydroelectric facilities, going to the Water Rights Fund of the State Treasury. The Water Code authorizes the State Water Board to periodically adjust the fees and requires the State Water Board to revise the fee schedule each fiscal year, as necessary to conform to the revenue levels set forth in the annual Budget Act (Water Code, $§ 1525,1530 \& 13160.1$.). 
The water used (in cubic meters) is considered equal to the diversion rate multiplied by the length of the direct diversion season, and the total collection amount for storage, unless otherwise specified. If the permit or license includes both direct diversion and storage, the two amounts are additive, unless a total annual amount is specified. The royalties collected are paid to the Water Rights Fund of the State Treasury.

In the state of New York, in spite of the regulatory provisions providing for royalties, in practice, the New York Department of Environmental Conservation has not been charging fees to anyone as they haven't had any requests for licenses [52].

In all cases, hydropower royalties are only paid by private owners-plants owned by governments do not pay these fees.

Table 6. Hydropower royalty rates in the US's largest hydropower states (production $\geq 10 \mathrm{TWh}$ ).

\begin{tabular}{|c|c|c|}
\hline Regulator & Annual Charge Basis & Royalty Rates \\
\hline $\begin{array}{l}\text { Federal Energy Regulatory } \\
\text { Commission (FERC) }\end{array}$ & $\begin{array}{l}\text { Non-federal hydro only Based on } \\
\text { FERC's administrative costs }\end{array}$ & $\begin{array}{l}\text { Complex rate structure depending on capacity, } \\
\text { power output, pumped storage and charge } \\
\text { factor } \approx \$ 0.48 / \mathrm{MWh}\end{array}$ \\
\hline Washington & Capacity & $\begin{array}{c}\leq 746 \mathrm{~kW} \quad \$ 0.2413 / \mathrm{kW} \\
\text { between } 746 \text { and } 7460 \mathrm{~kW} \$ 0.0483 / \mathrm{kW} \\
>7460 \mathrm{~kW} \$ 0.0241 / \mathrm{kW}\end{array}$ \\
\hline $\begin{array}{l}\text { FERC administered project } \\
\text { (in addition to the base charge) }\end{array}$ & Capacity & $\begin{array}{c}\leq 746 \mathrm{~kW} \quad \$ 0.4290 / \mathrm{kW} \\
\text { between } 746 \text { and } 7460 \mathrm{~kW} \$ 0.0858 / \mathrm{kW} \\
>7460 \mathrm{~kW} \$ 0.0429 / \mathrm{kW}\end{array}$ \\
\hline Oregon & Capacity & $\begin{array}{c}\leq 92.1 \mathrm{~kW} \quad \$ 0.5429 / \mathrm{kW} \\
>92.1 \mathrm{~kW} \$ 50\end{array}$ \\
\hline New York & No charge & No royalties \\
\hline California & $\begin{array}{l}\text { Permit \& license fee } \\
\text { Water } \\
\text { Capacity }\end{array}$ & $\begin{array}{c}\$ 150+\$ 0.051 / 1000 \mathrm{~m}^{3}>12,335 \mathrm{~m}^{3} \\
\$ 1000+\$ 12.16 / 1000 \mathrm{~m}^{3}>12,335 \mathrm{~m}^{3} \\
\$ 100+\$ 0.125 / \mathrm{kW}\end{array}$ \\
\hline
\end{tabular}

\subsubsection{Royalty Distribution Policy}

The FERC determines a fee for headwater benefits (CFR, Title 18, Chapter 1, Subchapter B, Part 11 $\S 11.10$ ), which implies a charge for the benefits provided to downstream users of regulated water from an "upstream" headwater project. Benefits are in the form of increased energy generation at downstream hydro projects. The project owners pay a portion of the capital costs of the headwater project in proportion of the energy gain benefits they receive.

The FERC establishes and collects payments for headwater benefits on behalf of federal project owners. The collected money returns to the US Treasury (US Corps of Engineers, Bureau of Reclamation).

In general, at the federal and at the state levels (Oregon and New York), charges are based on an administrative and operational cost-recovery principle, without any consideration for the negative externalities related to dams. Similarly, in California, royalties are going to the Water Fund to cover costs of the administration system.

Moreover, as noted before, exempting hydropower project owned by the US government from royalty payment does not encourage public owners to consider the real value of water and hydropower energy.

\section{Discussion}

Historically, governments across the world have chosen to keep royalty rates [6,7], and hence hydropower prices, low to promote industrialization. This is the case for the four main hydropower producers we study. One notable exception is Switzerland, where hydropower royalty rates are about $\$ 10 / \mathrm{MWh}$ [53]. These policies should be revised as they do not promote efficiency and the reduction of environmental and social costs, in order to ensure sustainable development [4]. Moreover, exemption 
of royalties for government-owned hydropower producers, as in the United States, does not encourage public owners to value the societal benefits of these sources of energy.

Charging lower water royalty rates and exempting some producers is a way to keep production costs artificially low and, as a consequence, to artificially decrease the overall average price of electricity. This appears to be the case in all jurisdictions reviewed in this paper, with royalty rates ranging from $\$ 0$ to a maximum of $\$ 3.8 / \mathrm{MWh}$ (Ontario and Quebec, Canada). It has been particularly documented in Ontario, where royalty rates were considered to be below the market value of the production of hydro-electricity [23].

This situation also increases the negative externalities associated from hydropower, as it unfairly promotes its development. Furthermore, most of the damages generated by the construction of dams are never recovered. In fact, as it has been shown, most states do not provide a royalty for covering and, in the same way, internalizing the negative externalities that hydropower sites have produced. Indeed, at the moment, externalities are generally not reflected in the market prices, so the external costs associated with the production are borne neither by consumers nor producers.

That's why hydropower royalty systems should include the cost of those externalities, even if it raises the price of electricity [17]. It is true that, on one hand, collecting the full amount of hydroelectric royalties would have adverse effects on residential, commercial, and industrial consumers of electricity. An increase in electrical rates will affect their costs and hence what they may charge for the goods and services that they produce [23]. However, on the other hand, higher royalty rates intended to cover negative externalities would in fact be more equitable to those who support the higher costs of the construction of dams (local populations and the environment). In addition, while higher rates have an impact on the price of electricity, they also encourage a lower energy consumption and, therefore, promote the conservation of water and aquatic resources. This is what some authors call the "value gap" [12], which, in our case, is the gap between current royalty rates and the full cost of societal and environmental value of water and energy. If this situation stays as it is in the four countries that we have studied, we can hardly expect improvements in water and energy management. This leads to some forms of the "tragedy of the commons": overexploitation of common resources.

Increasing hydropower royalties will induce institutional as well as political and stake-holder opposition [12]. This reaction can be somewhat alleviated by the creation of a determined water conservation fund, as in California.

The case of Brazil shows an example of financial compensation from hydropower companies dedicated to the environment and local communities. In fact, contrary to the Quebec practice, Brazil has outlawed the use of royalties to reimburse debts and for public expenses, and has chosen to use these funds for environmental and social purposes. Some studies have demonstrated that municipalities receiving financial compensation effectively present a progress in social and economic indicators when compared to the situation before and after the receipt of the financial compensation [54]. Nevertheless, in this country, regarding the environmental aspects, it seems that the financial compensation is not enough to mitigate externalities arising from the construction of hydroelectric power plants [12].

In Quebec, despite the fact that royalties are exclusively intended to repay the public debt, Hydro-Quebec has voluntarily created an environmental fund to compensate local communities and the environment.

Finally, this study shows that royalty and distribution policies are determined in an arbitrary and unsystematic manner. This leads to a heterogeneity that undermines the creation of a level-playing field for hydropower development and use. In fact, the different approaches we document here illustrate how water use is undervalued. A more harmonized royalty system, starting at the national level, would be a significant policy improvement. Adopting such a more uniform system of royalties should become a priority, as economies and issues are increasingly becoming global. Furthermore, in a context of climate change, key renewable resources such as hydropower should continue to be developed, but in a sustainable and responsible way, where production and use are properly valued. 


\section{Conclusions}

This study has shown that the leading hydropower producing countries, China, Brazil, Canada and the United States, are differently organized regarding hydropower royalties. If in Canada the primary responsibility clearly belongs to provinces, in China, the central government plays a much larger role. The United States and Brazil have centralized many aspects of the management of hydropower at the federal level with, nonetheless, a contrast between the autonomy American states have in creating local rules and the uniformity imposed to Brazilian states.

This study has revealed that the current royalty's approaches may vary considerably between regions, even inside the same country. The most common criterion that has been identified to charge royalties is hydropower generation. Nevertheless, the application schemas can be very different. Furthermore, royalty practices are not subject to regular updates in all jurisdictions and don't equally apply to all.

Few cases include the principle of compensating negative externalities in royalty rates. Only Brazil appears to clearly consider this cost in the foundations of the royalty's system, even if in Canada, the United States and China, we can identify some cases where water conservation concerns are considered.

Therefore, some recommendations could be put forward, such as the need for countries to adopt a royalty system that considers compensating for damages to local communities and to the environment. While it may be argued that the establishment of a new rate would increase the price of access to electricity for final consumers, it is worth adopting a long-term vision in which governments internalize environmental and social costs. Those policies should also integrate some equity principles, to protect low-income consumers.

Acknowledgments: This paper benefited from the work of different research assistants: Maïte Abadie and Emmanuel Demars in particular. Information on China comes mostly from the M.Sc. supervised project realized by Hui Zhou. We would like to thank Caroline Archambault and Gabrielle Malenfant, from the library of HEC Montréal for their bibliographic support. The authors are grateful to HEC Montréal's Chair in Energy Sector Management for financial assistance.

Author Contributions: Pierre-Olivier Pineau instigated the research and coordinated the data collection. He is also responsible for a third of the analysis and of the writing. Lucile Tranchecoste collected most of the data and is responsible for a third of the writing. Yenny Vega-Cárdenas contributed to the analysis of the data and for the last third of the writing.

Conflicts of Interest: The authors declare no conflict of interest.

\section{References}

1. International Energy Agency (IEA). Key World Energy Statistics; International Energy Agency: Paris, France, 2016.

2. U.S. Department of Energy. Benefits of hydropower. Available online: http://energy.gov/eere/water/ benefits-hydropower (accessed on 22 August 2015).

3. UNEP (United Nations Environmental Programme). Dams and Development-Relevant Practices for Improved Decision-Making, A Compendium of Relevant Practices for Improved Decision-Making on Dams and Their Alternatives; United Nations Environmental Programme: Nairobi, Kenya, 2007.

4. Gibbons, J.; Fracassi, J. Tax Shift: Eliminating Subsidies and Moving to Full Cost Electricity Pricing; Ontario Clean Air Alliance Research Inc.: Toronto, ON, Canada, 2008.

5. Rothman, M. Measuring and Apportioning Rents from Hydroelectric Power Developments; WDP419; The World Bank: Washington, DC, USA, 2000.

6. Brubaker, E. Water Charges to Hydroelectricity Producers: An International Survey; EP-363; Energy Probe: Toronto, ON, Canada, 1992.

7. UNIPEDE (International Union of Producers and Distributors of Electrical Energy). Taxes on Hydroelectric Use of Water. Hydro-Power and Other Renewable Energies. Study Committee 30-03 Hydrouses; UNIPEDE: Paris, France, 1993.

8. General Accounting Office (GAO). Charges for Hydropower Projects' Use of Federal Lands Need to Be Reassessed; GAO-03-383; United States General Accounting Office: Washington, DC, USA, 2003.

9. Guelph Water Management Group. Characterization of Water Allocation Systems in Canada; Technical Report 1; University of Guelph: Guelph, ON, Canada, 2007. 
10. Myszewski, M.; Christy, D.R.; Kundell, J.E. A Comparison of Surface Water Laws and Regulations from Southeastern States; Carl Vinson Institute of Government, University of Georgia: Athens, Greece, 2005.

11. Salman, S.M.A.; Bradlow, D.D. Regulatory Frameworks for Water Resources Management. A Comparative Study; Discussion Paper 36216; The World Bank: Washington, DC, USA, 2006.

12. Sawyer, D.; Perron, G.; Trudeau, M. Analysis of Economic Instruments for Water Conservation, Final Report; Marbek Resource Consultants: Ottawa, ON, Canada, 2005.

13. Massarutto, A.; Pontoni, F. Rent seizing and environmental concerns: A parametric valuation of the Italian hydropower sector. Energy Policy 2015, 78, 31-40. [CrossRef]

14. Glachant, J.-M.; Saguan, M.; Rious, V.; Douguet, S.; Gentzoglanis, E. Regimes for Granting Rights to Use Hydropower in Europe; Research report; European University Institute: Florence, Italy, 2014.

15. United Nations. Water a Shared Responsibility. The United Nations World Water Development Report 2; United Nations Educational, Scientific and Cultural Organization (UNESCO): Paris, France, 2006.

16. WWAP (United Nations World Water Assessment Programme). The United Nations World Water Development Report 2014. Water and Energy; United Nations Educational, Scientific and Cultural Organization: Paris, France, 2014.

17. Houston, L.L.; Kline, J.D.; Alig, R.J. Economics Research Supporting Water, Resource Stewardship in the Pacific Northwest; General Technical Report PNW-GTR-550, U.S. Department of Agriculture, Forest Service, Pacific Northwest Research Station: Portland, ND, USA, 2002.

18. Dinar, A.; Subramanian, A. Water Pricing Experiences: An International Perspective; Technical paper No. 386; The World Bank: Washington, DC, USA, 1997.

19. Sigg, R.; Röthlisberger, W. La Redevance Hydraulique - Principale Taxe Frappant L'utilisation de la Force Hydraulique en Suisse; Rapports de l'ofeg; 3; Federal Office for Water and Geology: Berne, Switzerland, 2002.

20. Imhof, A.; Lanza, G.R. Greenwashing hydropower. World Watch 2010, 23, 8-14.

21. WCD (World Commission on Dams). Dams and Development: A New Framework for Decison-Making; Earth Publications: London, UK, 2000.

22. MacGeorge, R.; Stewart, J.B.; Vostroknutova, E. Fiscal Regime in the Hydro Power Sector; Technical Note, Lao PDR Development Report 2010, Natural Resource Management for Sustainable Development; The World Bank: Washington, DC, USA, 2010.

23. Gillen, D.; Wen, J.-F. Taxing hydroelectricity in Ontario. Can. Public Policy/Anal. Polit. 2000, 26, 35-49. [CrossRef]

24. BP. BP Statistical Review of World Energy June 2016; BP: London, UK, 2016.

25. Government of China. Power Transmission from West to East China: Turning a Natural Resource into Economic Benefit, a Win-Win Relationship (Free Translation). Available online: http://www.gov.cn/jrzg/ 2008-11/15/content_1149889.htm (accessed on 22 July 2015).

26. China Census for Water. Bulletin of First National Census for Water; Ministry of Water Resources, National Bureau of Statistics: Beijing, China, 2013.

27. Zhou, H. La Redevance Hydraulique en Chine: Évolution et Différences Provinciales. Master's Thesis, HEC Montréal, Montréal, QC, Canada, 2011.

28. Government of China. CPC Central Committee and State Council on Accelerating the Development of Water Reform (Free Translation). Available online: http://www.gov.cn/jrzg/2011-01/29/content_1795245.htm (accessed on 22 July 2015).

29. State Council of China. Regulation on the Administration of the License for Water Drawing and the Levy of Water Resource Fees; 460; SCC: Beijing, China, 2006.

30. Government of China. Water Permits and Water Fee Collection Regulations (Free Translation). Available online: http:/ /www.gov.cn/ziliao/flfg/2006-03/06/content_220450.htm (accessed on 22 July 2015).

31. De Almeida, E.; Dos Santos, E.; Dubeux, C.; Eduardo, M.; Motta, G.; Goldemberg, J.; La Rovère, E.; Lizardo de Arauji, J.A.; Schaeffer, R.; Simoes, A.J.; et al. The energy situation in Brazil: An overview. In World Energy Outlook 2006; van Dulst, N., Ed.; Organisation for Economic Co-operation and Development, International Energy Agency: Paris, France, 2006; pp. 447-487.

32. Agência Nacional de Energia Elétrica. Compensação Financeira pela Utilização de Recursos Hídricos para Geração de Energia Elétrica; ANEEL: Brasilia, Brasil, 2005.

33. Agência Nacional de Energia Elétrica. Compensação Financeira. Processo de Arrecadação. Available online: http:/ / www2.aneel.gov.br/area.cfm?idArea=536\&idPerfil=2 (accessed on 22 July 2015). 
34. Environment Canada. Water and Canada: Preserving a Legacy for People and the Environment; Government of Canada: Ottawa, ON, Canada, 2003.

35. Vega Cardenas, Y.; Vega, N.B. L'eau douce, son exportation et le droit constitutionnel Canadien. Les Cahiers de Droit 2010, 51, 771-800. [CrossRef]

36. Environment Canada. Water Governance and Legislation. Available online: http://www.ec.gc.ca/eauwater/default.asp?lang=En\&n=87922E3C-1 (accessed on 22 July 2015).

37. Statistics Canada. Report on Energy Supply and Demand in Canada-2013 Preliminary; 57-003-X; Statistics Canada: Ottawa, ON, Canada, 2015.

38. Paradis, S. Ressources naturelles. L'umq veut des redevances. Le Soleil, 30 January 2015; p. 24.

39. Environment Canada. Water Charges to Power Companies in Canada; Environment Canada: Ottawa, ON, Canada, 1990.

40. BC Ministry of the Environment. Detailed Fees and Rentals Schedule to Be Implemented in 2016; Government of British Colombia: Victoria, BC, Canada, 2015; p. 8.

41. Government of New Brunswick. Wind Power Production on Crown Land; Fact Sheet; Governement of New Brunswick: Fredericton, NB, Canada, 2015.

42. Alberta Ministry of Agriculture and Forestry. Hydroelectric Power. Available online: http:/ /www1.agric. gov.ab.ca/ \protect $\backslash \mathrm{T} 1 \backslash$ textdollardepartment/deptdocs.nsf/all/eng4431 (accessed on 18 April 2017).

43. Government of Saskatchewan. The Water Power Rental Regulations; W-6 Reg 2; Government of Saskatchewan: Regina, SK, Canada, 2013; p. 6.

44. Hydro-Quebec. Investing in Communities. Available online: http://www.hydroquebec.com/sustainabledevelopment/collective-choices/investing-communities.html (accessed on 23 July 2015).

45. Ontario. New, Redeveloped and Upgraded Hydro-Electric Generating Stations-Ministry of Natural Resources' Statements Issued for the Purpose of Claiming Deductions to the Gross Revenue Charge under the Electricity Act, 1998; WR 3.02.01; Ministry of Natural Resources: Toronto, ON, Canada, 2008; p. 25.

46. U.S. Energy Information Administration. Electric Power Annual with Data for 2013; US Department of Energy: Washington, DC, USA, 2015.

47. Kao, S.-C.; McManamay, R.A.; Stewart, K.M.; Samu, N.M.; Hadjerioua, B.; DeNeale, S.T.; Yeasmin, D.; Pasha, M.F.K.; Oubeidillah, A.A.; Smith, B.T. New Stream-Reach Development: A Comprehensive Assessment of Hydropower Energy Potential in the United States; Oak Ridge National Laboratory: Oak Ridge, TN, USA, 2014.

48. Hall, D.G.; Reeves, K.S. A Study of United States Hydroelectric Plant Ownership; INL/EXT-06-11519; INL Idaho National Laboratory: Idaho Falls, IA, USA, 2006; p. 27.

49. Oregon Revised Statutes. Hydroelectric Projects, Vol. 13, c-543, s543.280; Oregon State Legislature: Salem, OR, USA, 2009.

50. New York Environmental Conservation Law, Article 15, Water Resources, Title 17, § 15-1707. Available online: http:/ /law.justia.com/codes/new-york/2006/environmental-conservation/env015-1707_15-1707. html (accessed on 18 April 2017).

51. FERC (Federal Energy Regulatory Commission). Annual Charges. Available online: http://www.ferc.gov/ industries/hydropower/annual-charges.asp (accessed on 24 July 2015).

52. Little, W. Re: Information Request on Water Power Rental Fee; Demars, E., Ed.; E-mail Exchange: Montreal, QC, Canada, 2010.

53. Plot, M.; Pfammater, R. Flexibilisation des Redevances Hydrauliques: Une Chance Pour Tous; Bulletin SEV/VSE 2017; Rédaction Electrosuisse: Fehraltorf, Zurich, Switzerland, 2017.

54. Mendonça, L. O Legado das Hidreléctricas. Available online: https://www.osetoreletrico.com.br/2016/ 2011/10/19/o-legado-das-hidreletricas/ (accessed on 19 April 2017).

(c) 2017 by the authors. Licensee MDPI, Basel, Switzerland. This article is an open access article distributed under the terms and conditions of the Creative Commons Attribution (CC BY) license (http:/ / creativecommons.org/licenses/by/4.0/). 